\title{
Recent Scientific Publications Cast Doubt on North Atlantic Right Whale Future
}

\author{
Scott D. Kraus ${ }^{1 *}$, Robert D. Kenney ${ }^{2}$, Charles A. Mayo ${ }^{3}$, William A. McLellan ${ }^{4}$, \\ Michael J. Moore ${ }^{5}$ and Douglas P. Nowacek ${ }^{6}$ \\ ${ }^{1}$ New England Aquarium, Boston, MA, USA, ${ }^{2}$ Graduate School of Oceanography, University of Rhode Island, Narragansett, \\ RI, USA, ${ }^{3}$ Right Whale Ecology Program, Provincetown Center for Coastal Studies, Provincetown, MA, USA, ${ }^{4}$ Biology and \\ Marine Biology, University of North Carolina, Wilmington, NC, USA, ${ }^{5}$ Biology Department, Woods Hole Oceanographic \\ Institution, Woods Hole, MA, USA, ${ }^{6}$ Nicholas School of the Environment and Pratt School of Engineering, Duke University \\ Marine Laboratory, Duke University, Beaufort, NC, USA
}

Keywords: right whales, conservation, mortalities, entanglements, population recovery

OPEN ACCESS

Edited by:

Graeme Clive Hays,

Deakin University, Australia

Reviewed by:

Luis Cardona,

University of Barcelona, Spain

Fredrik Christiansen,

Murdoch University, Australia

*Correspondence:

Scott D. Kraus

skraus@neaq.org

Specialty section:

This article was submitted to

Marine Megafauna,

a section of the journa

Frontiers in Marine Science

Received: 30 March 2016

Accepted: 25 July 2016

Published: 17 August 2016

Citation:

Kraus SD, Kenney RD, Mayo CA,

McLellan WA, Moore MJ and

Nowacek DP (2016) Recent Scientific

Publications Cast Doubt on North

Atlantic Right Whale Future.

Front. Mar. Sci. 3:137.

doi: 10.3389/fmars.2016.00137
The North Atlantic right whale, Eubalaena glacialis, was near extinction by 1935, when whaling for this species became illegal. In 1992, 295 right whales were estimated alive (Knowlton et al., 1994), and growth from 1990 to 2010 averaged 2.8\% per year (Waring et al., 2016), bringing the population to about 500 individuals in 2015 (Pettis and Hamilton, 2015). However, since 2010, calving rates have dropped by nearly $40 \%$, and the last four decades have seen increasing numbers of right whales killed by entanglements in fishing gear and collisions with ships combined (Knowlton et al., 2012; Van der Hoop et al., 2013; Pace et al., 2014). Recent U.S. and Canadian regulatory actions (slowing ships and moving shipping lanes) appear to have been successful at reducing ship kills (Laist et al., 2014; Van der Hoop et al., 2015).

However, the National Marine Fisheries Service (NMFS) draft 2015 marine mammal stock assessment for right whales reports that between 2009 and 2013 an average of 4.3 right whales were killed by human activities each year, with nearly all of these deaths attributable to entanglement in fishing gear (Waring et al., 2016). For context, from 1970 to 2009, 44\% of diagnosed RW mortality cases were due to ship kills and 35\% were due to entanglements (Van der Hoop et al., 2013). From 2010 to 2015, 15\% of diagnosed right whale mortalities were due to ship kills and 85\% were due to entanglements (Pettis and Hamilton, 2015; Waring et al., 2016). In January of 2016, an announcement on expanded critical habitat for right whales included this quote, "We're making significant progress in reversing the population decline of the species, and are seeing signs of recovery" (NOAA, 2016). In contrast to this optimistic view of right whale recovery, our review of the recent science suggests that fishing gear entanglements are increasing in number and severity, and that this source of injury and mortalities may be overwhelming recovery efforts.

Almost four decades of research based on the ability to identify individual whales has yielded immense amounts of information about this population's biology. The right whale catalog and sightings database provide information on the age and sex of individuals, movements and habitat use patterns, reproduction, mortality, and the impacts of human activities on the population (Hamilton et al., 2007). Multiple research programs run concurrently on genetics, endocrinology, health, feeding, stress, and acoustics in many institutions (Kraus and Rolland, 2007). From these large datasets, mathematical models that describe trends in population growth and demographics as well as the effects of human activities on health and mortality have been developed (Schick et al., 2013; Robbins et al., 2015; Rolland et al., 2016).

Since 1980, the leading causes of mortality in right whales have been collisions with ships and entanglements in fishing gear, which combined caused half of the 99 confirmed right whale deaths (Van der Hoop et al., 2013). That estimate is a minimum, since the other half includes natural 


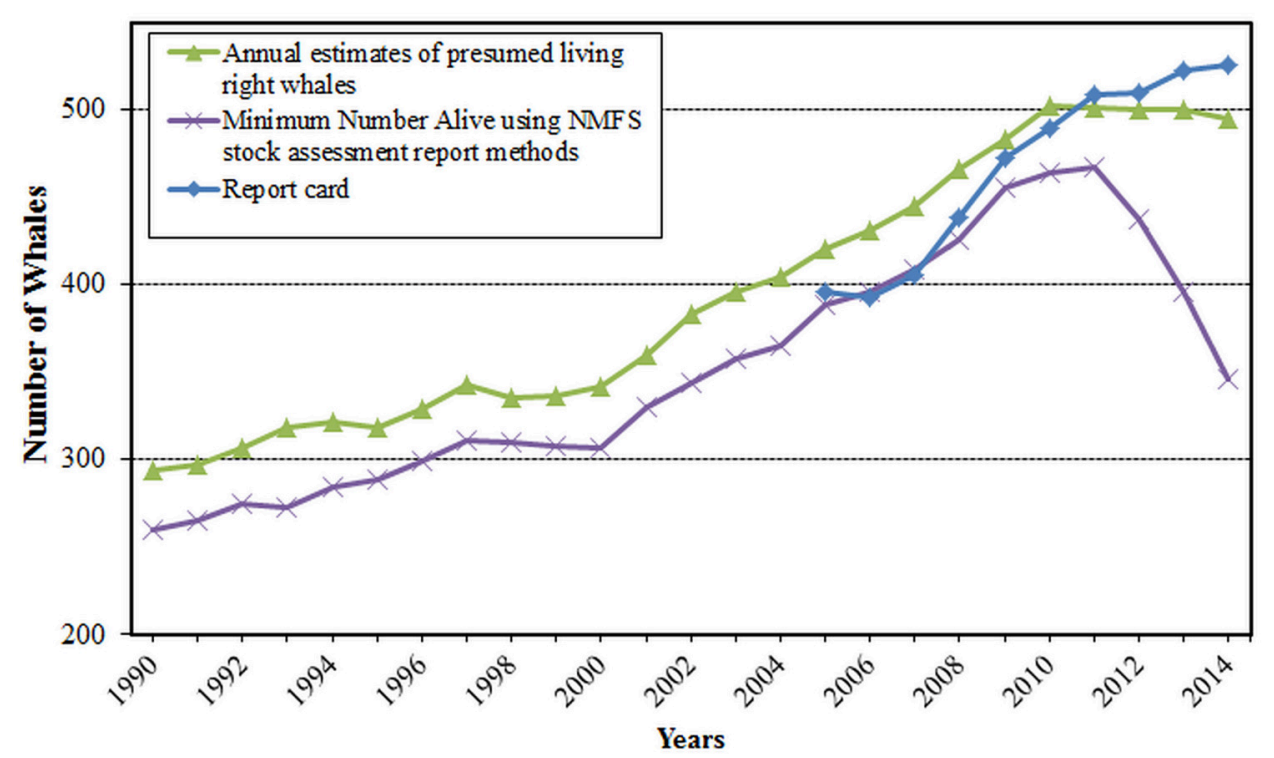

FIGURE 1 | Assessments of the North Atlantic right whale population based on three available assessment methods (from Pettis and Hamilton, 2015); (http://www.narwc.org/pdf/2015\%20Report\%20Card.pdf).

mortalities and deaths where the cause could not be determined, and not all dead whales were discovered. Since U.S. NOAA regulations lowered ship speed limits in the vicinity of right whale habitats in 2008, deaths from vessel strikes have declined (Laist et al., 2014; Van der Hoop et al., 2015). In contrast, despite a nearly 20-year US federal effort to reduce accidental kills of whales in fishing gear, sub-lethal and lethal entanglement rates have increased (Van der Hoop et al., 2013; Arthur et al., 2015; Knowlton et al., 2015), and there is no evidence that current fishing regulations have been effective at reducing mortality (Pace et al., 2014). As of 2015, 83\% of all right whales display scars or carry ropes indicative of past entanglements. Sublethal entanglements can cause reproductive failure and declining health long after the entanglement is over (Rolland et al., 2016; Van der Hoop et al., 2016).

Attempts at population viability analyses on right whales have largely failed due to the dual complications of capture heterogeneity (in tag-recapture population assessments) and small sample sizes. There are however early indicators of population well-being, including health assessments, scarring rates and frequencies, reproductive rates, and necropsy data, all of which precede changes in population size and demographics, and all of which indicate declines in this population (Knowlton et al., 2012; Pettis and Hamilton, 2015; Rolland et al., 2016).

From this extensive research, three points emerge. One, until recently, the population was growing at $2-3 \% /$ year (Waring et al., 2016), although this rate is less than one-half of the growth

\section{REFERENCES}

Arthur, L. A., McLellan, W. A., Piscitelli, M. A., Rommel, S. A., Woodward, B. L., Winn, J. P., et al. (2015). Estimating maximal force output of cetaceans rate $(6-7 \%)$ of all other well-studied right whale populations around the world (Best et al., 2001). Two, in recent years, population growth rates appear to be declining (Figure 1), likely due to a combination of anthropogenic mortalities and reduced calving rates (Kraus et al., 2007; Pettis and Hamilton, 2015). Three, mortalities and serious injuries from fishing gear entanglements remain far higher than the limits mandated by US Endangered Species Act and Canadian Species At Risk Act regulations, further jeopardizing recovery and leaving the population vulnerable to declines (Knowlton et al., 2015; Waring et al., 2016).

In conclusion, right whales are not yet a conservation success story. Right whales need immediate and significant management intervention to reduce mortalities and injuries from fishing gear, and managers need a better understanding about the causes of reduced calving rates before this species can be considered on the road to recovery. Failure to act on this new information will lead to further declines in this population's number and increase its vulnerability to extinction.

\section{AUTHOR CONTRIBUTIONS}

All authors have a long history ( $>20$ years) of research and significant contributions to right whale research in the North Atlantic. In the context of this paper, all authors have contributed data, analyses, writing, and editing, as well as conceptual development to this submission.

using axial locomotor muscle morphology. Mar. Mamm. Sci. 31, 1401-1426. doi: $10.1111 / \mathrm{mms} .12230$

Best, P. B., Bannister, J. L., Brownell, R. L. Jr., and Donovan, G. P. (2001). Right whales: worldwide status. J. Cetacean Res. Manage. (Special Issue) 2, 1-309. 
Hamilton, P. K., Knowlton, A. R., and Marx, M. K. (2007). "Right whales tell their own stories: the photo-identification catalog," in The Urban Whale: North Atlantic Right Whales at the Crossroads, eds S. D. Kraus and R. M. Rolland (Cambridge, MA: Harvard University Press), 75-104.

Knowlton, A. R., Hamilton, P. K., Marx, M. K., Pettis, H. M., and Kraus, S. D. (2012). Monitoring North Atlantic right whale Eubalaena glacialis entanglement rates: a 30 yr retrospective. Mar. Ecol. Prog. Ser. 466, 293-302. doi: 10.3354/meps09923

Knowlton, A. R., Kraus, S. D., and Kenney, R. D. (1994). Reproduction in North Atlantic right whales (Eubalaena glacialis). Can. J. Zool. 72, 1297-1305. doi: 10.1139/z94-173

Knowlton, A. R., Robbins, J., Landry, S., McKenna, H. A., Kraus, S. D., and Werner, T. (2015). Implications of fishing rope strength on the severity of large whale entanglements. Conserv. Biol. 30, 318-328. doi: 10.1111/cobi. 12590

Kraus, S. D., Pace, R. M. III., and Frasier, T. R. (2007). "High investment, low return: the strange case of reproduction in Eubalaena glacialis," in The Urban Whale: North Atlantic Right Whales at the Crossroads, eds S. D. Kraus and R. M. Rolland (Cambridge, MA: Harvard University Press), 172-199.

Kraus, S. D., and Rolland, R. M. (2007). The Urban Whale: North Atlantic Right Whales at the Crossroads. Cambridge, MA: Harvard University Press.

Laist, D. W., Knowlton, A. R., and Pendleton, D. (2014). Effectiveness of mandatory vessel speed limits for protecting North Atlantic right whales. Endang. Spec. Res. 23, 133-147. doi: 10.3354/esr00586

NOAA (2016). NOAA Expands Critical Habitat for Endangered North Atlantic Right Whales. Available online at: http://www.greateratlantic.fisheries.no aa.gov/mediacenter/2016/january/25_noaa_expands_critical_habitat_for_enda ngered_north_atlantic_right_whales.html

Pace, R. M. I. I. I., Cole, T. V. N., and Henry, A. G. (2014). Incremental fishing gear modifications fail to significantly reduce large whale serious injury rates. Endang. Spec. Res. 26, 115-126. doi: 10.3354/esr00635

Pettis, H. M., and Hamilton, P. K. (2015). North Atlantic Right Whale Consortium 2015 Annual Report Card. Report to the North Atlantic Right Whale Consortium, November 2015. Available online at: http://www.narwc.org/pdf/ 2015\%20Report\%20Card.pdf
Robbins, J., Knowlton, A. R., and Landry, S. (2015). Apparent survival of North Atlantic right whales after entanglement in fishing gear. Biol. Conserv. 191, 421-427. doi: 10.1016/j.biocon.2015.07.023

Rolland, R. M., Schick, R. S., Pettis, H. M., Knowlton, A. R., Hamilton, P. K., Clark, J. S., et al. (2016). Health of North Atlantic right whales (Eubalaena glacialis) over three decades: from individual health to demographic and population health trends. Mar. Ecol. Prog. Ser. 542, 265-282. doi: 10.3354/meps11547

Schick, R. S., Kraus, S. D., Rolland, R. M., Knowlton, A. R., Hamilton, P. K., Pettis, H. M., et al. (2013). Using hierarchical Bayes to understand movement, health, and survival in the endangered North Atlantic right whale. PLoS ONE 8:e64166. doi: 10.1371/journal.pone.0064166

Van der Hoop, J. M., Corkeron, P., Kenney, J., Landry, S., Morin, D., Smith, J., et al. (2016). Drag from fishing gear entangling North Atlantic right whales. Mar. Mamm. Sci. 32, 619-642. doi: 10.1111/mms.12292

Van der Hoop, J. M., Moore, M. J., Barco, S. G., Cole, T. V. N., Daoust, P.-Y., Henry, A. G., et al. (2013). Assessment of management to mitigate anthropogenic effects on large whales. Conserv. Biol. 27, 121-133. doi: 10.1111/j.15231739.2012.01934.x

Van der Hoop, J. M., Vanderlaan, A. S. M., Cole, T. V. N., Henry, A. G., Hall, L., Mase-Guthrie, B., et al. (2015). Vessel strikes to large whales before and after the 2008 Ship Strike Rule. Conserv. Lett. 8, 24-32. doi: 10.1111/conl.12105

Waring, G. T., Josephson, E., Maze-Foley, K., and Rosel, P. E. (eds.). (2016). US Atlantic and Gulf of Mexico. MarineMammal Stock Assessments - 2015. NOAA Technical Memorandum NMFS-NE-238.

Conflict of Interest Statement: The authors declare that the research was conducted in the absence of any commercial or financial relationships that could be construed as a potential conflict of interest.

Copyright (c) 2016 Kraus, Kenney, Mayo, McLellan, Moore and Nowacek. This is an open-access article distributed under the terms of the Creative Commons Attribution License (CC BY). The use, distribution or reproduction in other forums is permitted, provided the original author(s) or licensor are credited and that the original publication in this journal is cited, in accordance with accepted academic practice. No use, distribution or reproduction is permitted which does not comply with these terms. 